\title{
Engineering Properties of Lateritic Soils around Dall Quarry in Sango Area, Ilorin, Nigeria
}

\author{
Oladele A. Omotoso ${ }^{1}$, Olusola J. Ojo ${ }^{1} \&$ Emmanuel T. Adetolaju ${ }^{1}$ \\ ${ }^{1}$ Department of Geology and Mineral Sciences, University of Ilorin, Ilorin, Nigeria \\ Correspondence: Olusola J. Ojo, Department of Geology and Mineral Sciences, University of Ilorin, Ilorin, \\ Nigeria. E-mail: solafoluk@yahoo.com
}

Received: February 10, 2012 Accepted: February 28, 2012 Online Published: June 5, 2012

doi:10.5539/esr.v1n2p71

URL: http://dx.doi.org/10.5539/esr.v1n2p71

\begin{abstract}
Lateritic soils at the DALL Quarry in Ilorin metropolis (Sango area), southwestern Nigeria were investigated with respect to their geotechnical properties and their suitability as construction materials. The two samples collected fall within the basement complex and they overly the migmatite-gneiss complex rocks.

The grain size analysis shows that soil sample ADET 1 is silt-clayey, very gravelly sand while sample ADET 2 is gravelly, silt-clayey sand. Atterberg consistency limit test shows that ADET 1 has $40 \%$ liquid limit, $18.2 \%$ plastic limit, $21.8 \%$ plasticity index, $7.4 \%$ shrinkage limit and an activity of 0.95 (normal clay). ADET 2 has $46 \%$ liquid limit, $23.5 \%$ plastic limit, $22.5 \%$ plasticity index, $8.2 \%$ shrinkage limit and an activity of 0.63 . The soil samples are above the activity (A) line in the zone of intermediate plasticity (CL) which means that they are inorganic soils. The samples contain inactive clay suggesting little or no swelling tendency and therefore good for construction material and this would prohibit foundation failure during foundation settlement. The California Bearing Ratio $(\mathrm{CBR})$ values are $1-4 \%($ average $=2.5 \%)$ and 3-5\% (average $=4 \%$ ) in ADET 1 and ADET 2 respectively which means that they are good as sub-grade construction materials. The cohesion ranges from $60-100 \mathrm{Kpa}$ (average $=75 \%$ ) and the angle of internal friction ranges from $31^{\circ}-35^{\circ}$ with an average of $33^{\circ}$.
\end{abstract}

The geotechnical analyses results show that the soils have high bearing capacity with little or no volume change and therefore can be used as construction materials in engineering works. Thus, the soil could support shallow foundation, dam construction, homogeneous embankments, slope stability and sub-grade materials in road constructions.

Keywords: sub-grade, settlement, Sango, shrinkage, laterite, gravel

\section{Introduction}

Engineering properties of soils play a significant role in civil engineering construction works particularly in road constructions, foundations, embankments and dams to mention a few. This made imperative, the testing of soil, on which a foundation or superstructure is to be laid. This would determine its geotechnical suitability as a construction material. In recent times, the alarming rate at which lives are being lost due to collapsed buildings and road failures calls for a solution. The solution could be brought by critical geotechnical testing of the engineering soil. The present area is situated within latitudes $8^{\circ} 34^{\prime} \mathrm{N}$ and $8^{\circ} 32^{\prime} \mathrm{N}$ and longitudes $4^{\circ} 38^{\prime} 15^{\prime}$ ' $\mathrm{E}$ and $4^{\circ} 40^{\prime} \mathrm{E}$ (Figures 1 and 2). The rocks in the study area are mainly granite gneiss and banded gneiss with foliations.

Several authors have worked on the geotechnical properties of lateritic soils. Jackson (1980) reported that lateritic soils have been used successfully as base and sub-base materials in road construction. Vallerge et al. (1969) worked on laterite soil in connection with construction of road, highways and airfields. The engineering problems associated with lateritic soil were evaluated by Lyons et al. (1971). Balogun (1984) reported that the addition of lime to the soil increases its optimum moisture content, liquid limit, California Bearing Ratio (CBR) etc. Alao (1983) studied the engineering properties of some soil samples from Ilorin area and discovered that they could be stabilized by compaction and that the samples could yield maximum strength if they are compacted on the dry side of their optimum moisture content (omc). Ogunsanwo (1989) evaluated CBR and shear strength of some compacted lateritic soils from southwestern part of Nigeria. He reported CBR of $27 \%$ in un-soaked and $14 \%$ for soaked sample for laterite soils derived from Amphibolites. From mica schist, he 
obtained $10 \%$ for unsoaked and $9 \%$ for soaked samples. As such it will be suitable as sub-base material but its linear shrinkage of $10 \%$ is greater than the $8 \%$ maximum suggested for sub base material.

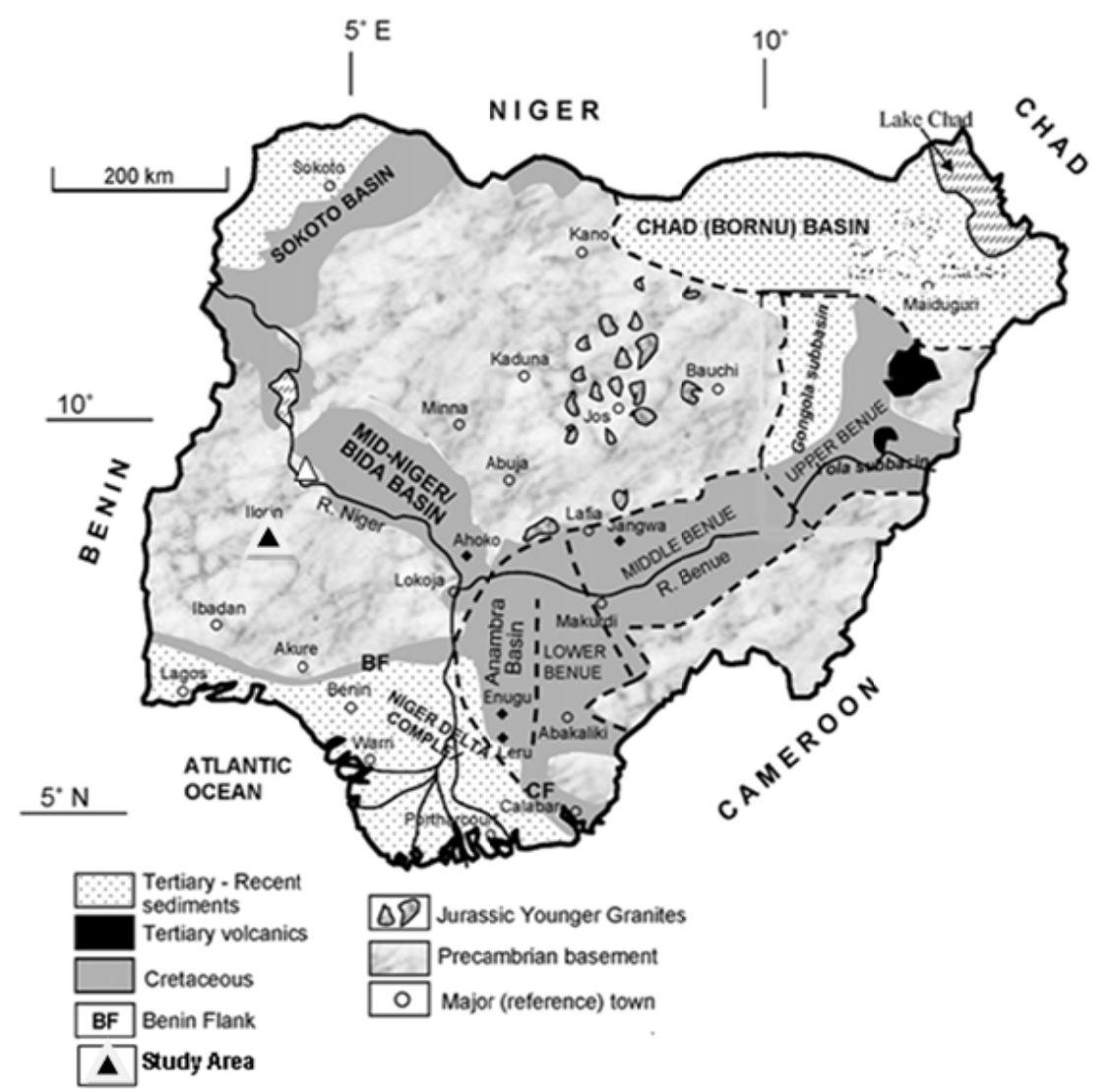

Figure 1. Geological Map of Nigeria showing the study area (Obaje et al., 2004)

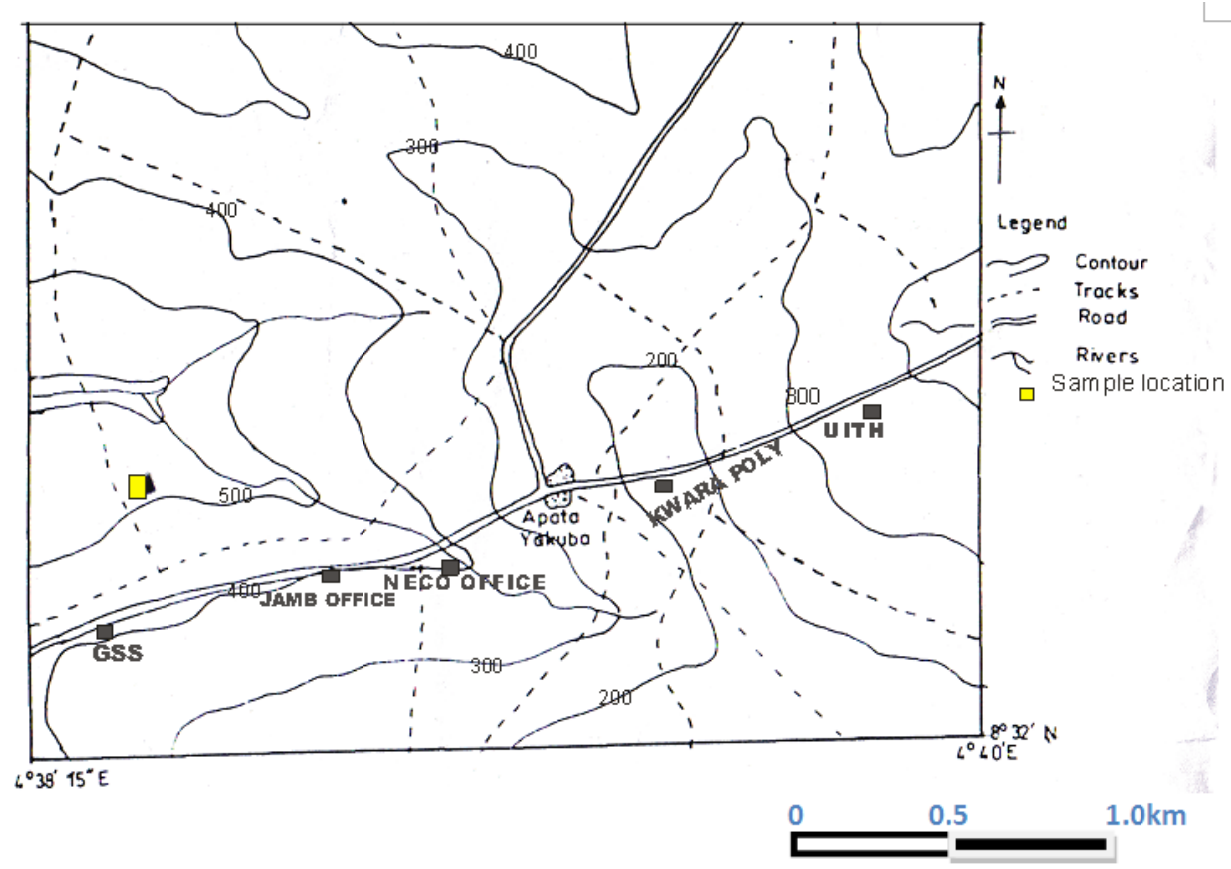

Figure 2. Sample location map showing sample locality 
Ogunsanwo (1988) also studied laterite soil from Ojota area in Lagos state and obtained liquid limit of 49.5\%, plastic limit of $21.8 \%$, plastic index of $28.4 \%$ and linear shrinkage of $6.9 \%$. On the basis of the geotechnical properties, he concluded that the soil is a good engineering construction material. Furthermore, Ogunsanwo (1989) performed CBR and shear strength tests on compacted lateritic soil from Benin sands. He then concluded that the compacted soil samples are suitable for use as sub-base materials in road construction as their CBR falls within the limits specified for this purpose $(7-20 \%)$.

This paper examines the geotechnical properties around DALL Quarry (a laterite soil quarry) soil in Ilorin, Southwestern Nigeria around where road construction is on-going.

\section{Materials and Methods}

Two lateritic soils were sampled (ADET 1 AND ADET 2) and selected for the various testing techniques. Grain-size analyses were performed using the convectional coarse sieve and fine sieve methods. The compaction test was carried out by standard and modified proctor methods. For the standard and modified proctor compaction test, the following materials were used: mould dimension of $10 \mathrm{~cm}$ by $5 \mathrm{~cm}$, weight of rammer $=2.5 \mathrm{~kg}$, no of layers $=5$, no of blows $=25$ but 55 for modified proctor and height of rammer $=11.5 \mathrm{~cm}$. The CBR tests (soaked CBR test and un-soaked CBR test) are determined using:

$$
\mathrm{CBR}=\frac{\text { test unit load }}{\text { Standard unit load }} \times 100
$$

The analyses were carried out at the Civil Engineering Laboratory, University of Ilorin, Nigeria.

\section{Results and Interpretations}

\subsection{Specific Gravity}

The results of the specific gravity analysis of both soil samples, ADET 1 and ADET 2 are 2.68 and 2.63 respectively. Comparing these results with some standard results or values, ADET 1 could be required as sand and ADET 2 could be required as inorganic clay (Bowles 1979). Table 1 presents the typical values of specific gravity of soil particles.

Table 1. Typical values of specific gravity of soil particles (Bowles, 1979)

\begin{tabular}{ll}
\hline Soil type & Specific Gravity \\
\hline Sand & $2.65-2.68$ \\
Gravel & $2.65-2.66$ \\
Clay(Inorganic) & $2.52-2.66$ \\
Clay(organic) & $2.68-2.72$ \\
Silt & $2.65-2.66$ \\
\hline
\end{tabular}

\subsection{Grain Size Distribution}

The test is performed to determine the percentage of different grain sizes contained within the soil. The distribution of different grain sizes affects the engineering properties of soil which in turn influences their usability in construction works. The grain size distribution shows that ADET 1 is silty-clayey very gravelly sand, having $23 \%$ silt, $23 \%$ clay, $47 \%$ sand and $30 \%$ gravel compositions. Similarly, ADET 2 could be described as gravelly silt-clayey sand with $36 \%$ silt, $36 \%$ clay, $52 \%$ sand and $12 \%$ gravel compositions.

\subsection{Atterberg Limits}

The Atterberg consistency limit tests carried out on the soil samples show that ADET 1 has liquid limit of $40.0 \%$, plastic limit of $18.2 \%$, plasticity index of $21.8 \%$, shrinkage limit of $7.4 \%$, toughness index of 1.16 and activity of 0.95 while ADET 2 it has liquid limit of $46.0 \%$, plastic limit of $23.5 \%$, plasticity index of $22.5 \%$, shrinkage limit of $8.2 \%$, activity of 0.63 and toughness index of 0.82 . The plots of plastic index against liquid limit on the plasticity chart show the Atterberg limits plots above "A" and it is in the zone of inorganic clayey silts, clays of low plasticity (CL) for both samples (Figure 3). This indicates Inorganic clays of low to medium plasticity, gravelly clays, sandy clay and silty clay. According to engineering use chart, the soil samples are impervious and inorganic clays useful for erosion resistance in canal constructions. They can also be useful in homogenous embankment in rolled earth dams because of their good to fair workability as construction materials and their fair shearing strength when compacted and saturated (Wagner, 1957). The values of activity (0.95 and 0.63 
respectively) also indicate inactive clay content which means that volume change is minimal and not problematic in the samples (DAS, 2006). The values obtained could also be compared with the values obtained by Ogunsanwo (1988) who concluded that 'the soil should be good engineering construction materials when compacted'.

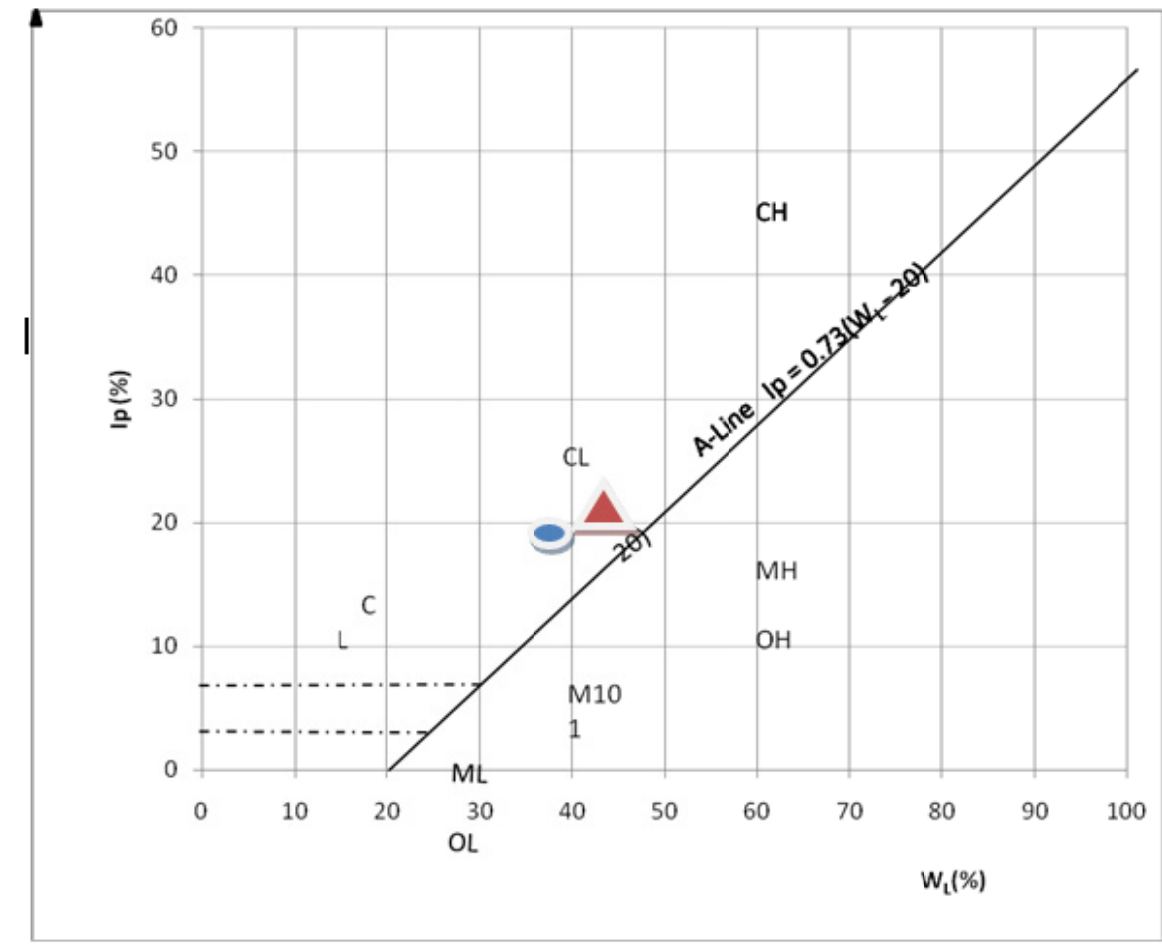

ADET1

ADET2

Figure 3. Plot of soil samples ADET 1 and ADET 2 on extended unified soil classification

\subsection{Compaction Test}

The standard proctor and modified proctor test variables, using $1000 \mathrm{~cm}^{3}$ moulds and the summary of compaction tests results are presented in Tables 2 and 3respectively. The compaction curves shows that dry density increases with increasing water content up to a maximum and later decrease. The maximum dry density (MDD) obtained for sample ADET1 is $1.85 \mathrm{~g} / \mathrm{cm}^{3}$ at standard proctor and $1.84 \mathrm{~g} / \mathrm{cm}^{3}$ at modified proctor. For sample ADET 2, the maximum dry density is $1.84 \mathrm{~g} / \mathrm{cm}^{3}$ at standard proctor and $1.90 \mathrm{~g} / \mathrm{cm}^{3}$ for modified proctor (Figure 4). This falls within the observed range of 1.3-2.4 g/ $\mathrm{cm}^{3}$ obtained by Ogunsanwo (1989), Madu (1975) and Gidigasu (1972). There is slight decrease of maximum dry density down the profile in this study. The optimum water content for sample ADET 1 is $14.0 \%$ at standard proctor and $13 \%$ at modified proctor. For ADET 2 the optimum moisture content is $15 \%$ at standard proctor and $14 \%$ at modified proctor. The optimum moisture content (OMC) serves as guide to know the amount of water to add during construction.

Table 2. Specific for standard proctor and modified proctor test variables, using $1000 \mathrm{~cm}^{3}$ mould

\begin{tabular}{lll}
\hline & Standard Proctor & Modified Proctor \\
\hline Weight of rammer $(\mathrm{kg})$ & 2.5 & 2.5 \\
Height of rammer drop $(\mathrm{cm})$ & 11.5 & 11.5 \\
Volume of mould $\left(\mathrm{cm}^{3}\right)$ & 1000 & 1000 \\
Number of layers & 3 & 5 \\
Number of blows & 25 & 55 \\
\hline
\end{tabular}


Table 3. Summary of compaction tests results

\begin{tabular}{lllll}
\hline Sample & \multicolumn{2}{l}{ Standard Proctor } & \multicolumn{2}{l}{ Modified Proctor } \\
\hline Number & OMC $(\%)$ & MDD $\left(\mathrm{g} / \mathrm{cm}^{3}\right)$ & OMC $(\%)$ & $\operatorname{MDD}\left(\mathrm{g} / \mathrm{cm}^{3}\right)$ \\
\hline ADET 1 & 14.0 & 1.85 & 13.0 & 1.84 \\
ADET 2 & 15.0 & 1.84 & 14.0 & 1.90 \\
\hline
\end{tabular}

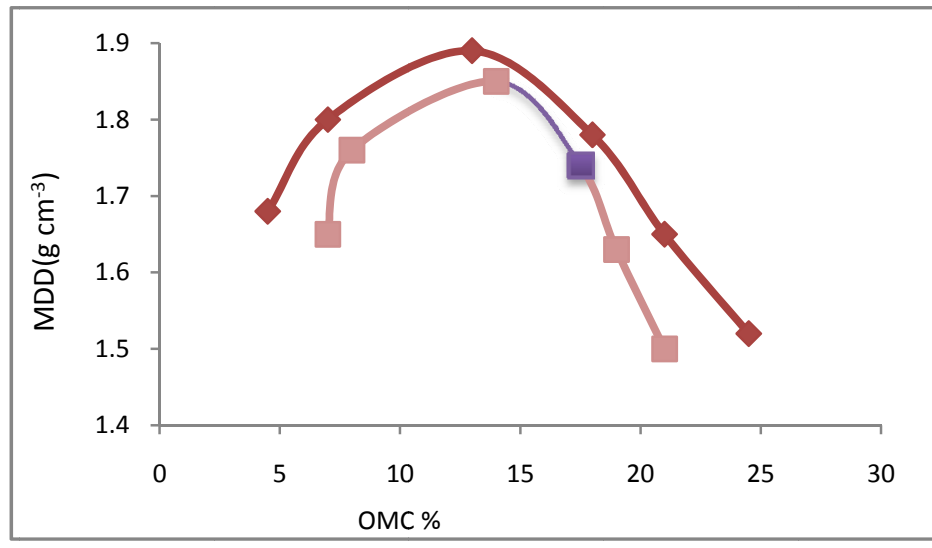

$\square$ Standard proctor

Modified proctor

Figure 4. Compaction curve for soil sample ADET 1 standard and 1 modify

\subsection{California Bearing Ratio (CBR) Tests}

The results of the CBR and the interpretations are presented in Tables 4 and 5 respectively. For standard proctor unsoaked and soaked, ADET1 has 3\% CBR and 1\% CBR values respectively. ADET2 also has 4\% CBR values respectively. Similarly, modified proctor unsoaked and soaked, ADET1 has $4 \%$ and $2 \%$ CBR values respectively and $\mathrm{ADET} 2$ has 5\% and 3\% CBR values respectively. Considering the values obtained, they fall within CBR value range of $0-3 \%$ and $3-7 \%$ respectively (Bowles, 1990), hence, the soils could be useful for slope stability, homogeneous embankment, core of roll earth dams and as sub-grade materials for road constructions.

Table 4. Summary of CBR tests results

\begin{tabular}{lcccc}
\hline Sample Number & \multicolumn{2}{c}{ Standard proctor \% } & \multicolumn{2}{c}{ Modified proctor \% } \\
\cline { 2 - 5 } & Unsoaked \% & Soaked \% & Unsoaked \% & Soaked \% \\
\hline ADET 1 & 3 & 1 & 4 & 2 \\
ADET 2 & 4 & 4 & 5 & 3 \\
\hline
\end{tabular}

Table 5. General rating of soil materials using CBR values (After Bowles, 1990)

\begin{tabular}{llll}
\hline CBR Value & General & Uses & Classification System \\
\hline $0-3$ & VERY POOR & Sub-grade & OH,CH,MH,OL \\
$3-7$ & Poor-fair & Sub-grade & OH,CH,MH,OL \\
$7-20$ & Fair & Sub-grade & OL,CL,ML,SC,SM,SP \\
$20-50$ & Good & Base, Sub-grade & GM,GC,SW,SM,SP,GP \\
50 & Excellent & Base & GW,GM \\
\hline
\end{tabular}

\subsection{Direct Shear Tests}

The direct shear test is used to determine the angle of internal friction of soil, the cohesion of the soil and the effective pressure. The test shows that soil sample ADET 1 compacted at standard proctor exhibits cohesion value of $70 \mathrm{Kpa}$ and angle of internal friction of $34^{\circ}$, when compacted at modified proctor, the cohesion (C) is $100 \mathrm{Kpa}$ and angle of internal friction $32^{\circ}$. Sample ADET 2 compacted at standard proctor has cohesion of $60 \mathrm{Kpa}$ 
and internal friction of $35^{\circ}$. When compacted at modified proctor, the cohesion is $70 \mathrm{Kpa}$ and angle of internal friction is $31^{\circ}$. The graphical representation is shown in Figures 5-8. The shear box test revealed that the soils are of high strength having cohesion values ranging from $60 \mathrm{Kpa}$ to $100 \mathrm{Kpa}$ with an average of $75 \mathrm{Kpa}$. Similarly, the angle of internal friction ranges from $31^{\circ}$ to $35^{\circ}$ with an average of $33^{\circ}$. Alao and Opaleye (2011) obtained an average value of cohesion, $65 \mathrm{Kpa}$ and an average value of angle of internal resistance, $26^{\circ}$. These values show that the soils have high bearing capacity as a result of their respective high cohesion and angle of internal friction values. It can therefore be deduced from the results of the test that the soil samples have a medium angle of internal friction which implies that the soils are hard according to the above references. Hence, the soils could support slope stability and shallow foundation.

Table 6a. ADET 1 standard proctor shear strength reading

\begin{tabular}{lll}
\hline Load $(\mathrm{kg})$ & Shear Stress & Normal Stress \\
\hline 5 & 166 & 138.9 \\
10 & 269 & 277.8 \\
15 & 358 & 416.7 \\
20 & 433 & 555.6 \\
\hline
\end{tabular}

Cohesion=70Kpa, Angle of internal friction $\Phi=340$

Table 6b. ADET 1 modified proctor shear strength reading

\begin{tabular}{lll}
\hline Load $(\mathrm{kg})$ & Shear Stress & Normal Stress \\
\hline 5 & 186 & 138.9 \\
10 & 304 & 277.8 \\
15 & 372 & 416.7 \\
20 & 454 & 555.6 \\
\hline
\end{tabular}

Cohesion $=100 \mathrm{Kpa}$, Angle of internal friction $\Phi=320$

Table 6c. ADET 2 standard proctor shear strength reading

\begin{tabular}{lll}
\hline Load $(\mathrm{kg})$ & Shear Stress & Normal Stress \\
\hline 5 & 160 & 138.9 \\
10 & 269 & 277.8 \\
15 & 359 & 416.7 \\
20 & 433 & 555.6 \\
\hline
\end{tabular}

Cohesion $=60 \mathrm{Kpa}$, Angle of internal friction $\Phi=350$

Table 6d. ADET 2 modified proctor shear strength reading

\begin{tabular}{lll}
\hline Load $(\mathrm{kg})$ & Shear Stress & Normal Stress \\
\hline 5 & 153 & 138.9 \\
10 & 231 & 277.8 \\
15 & 320 & 416.7 \\
20 & 428 & 555.6 \\
\hline
\end{tabular}

Cohesion $\mathrm{C}=70 \mathrm{Kpa}$, Angle of internal friction $\Phi=31^{0}$ 


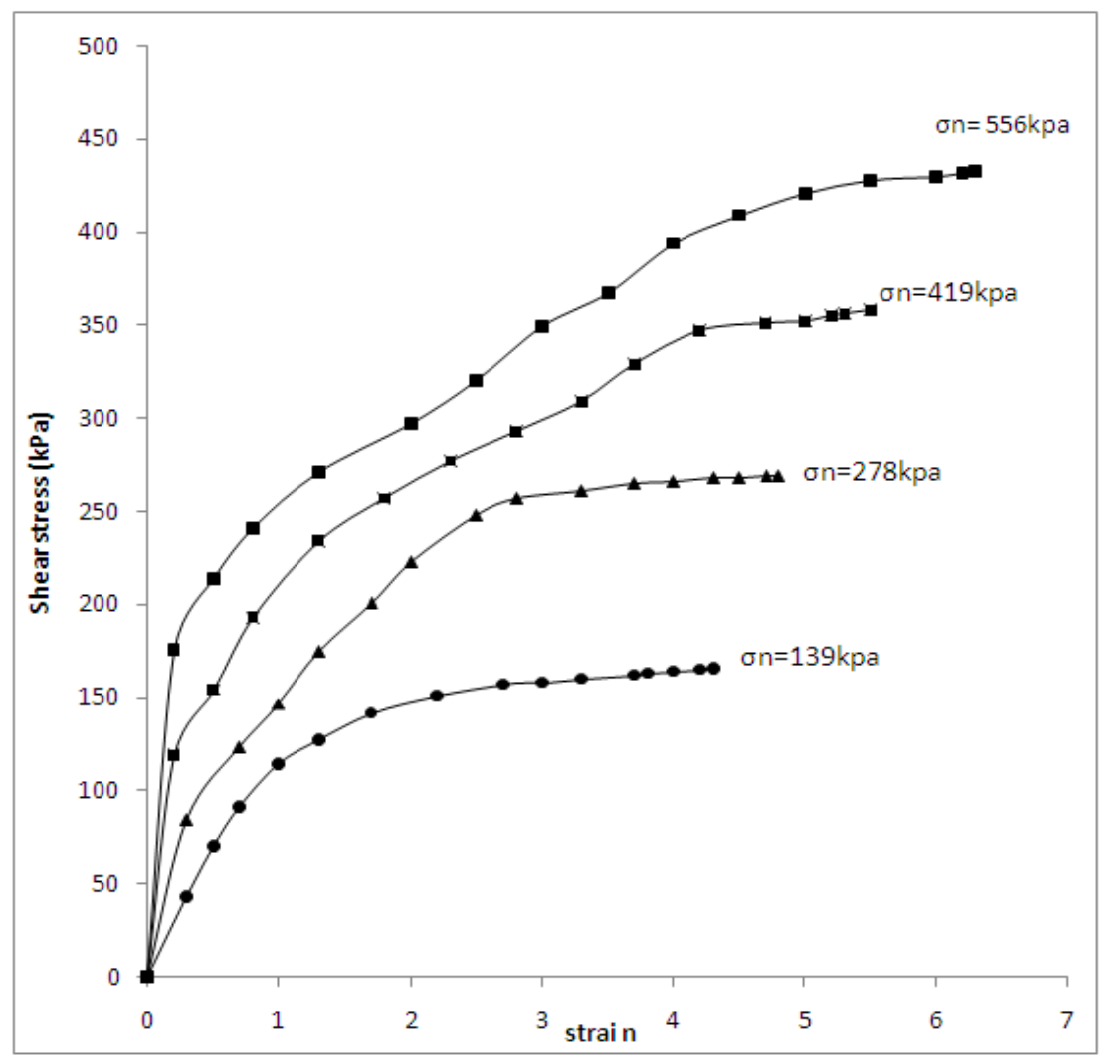

Figure 5a. Plots of shear stress (kpa) vs strain (\%) for standard proctor compacted soil sample ADET 1

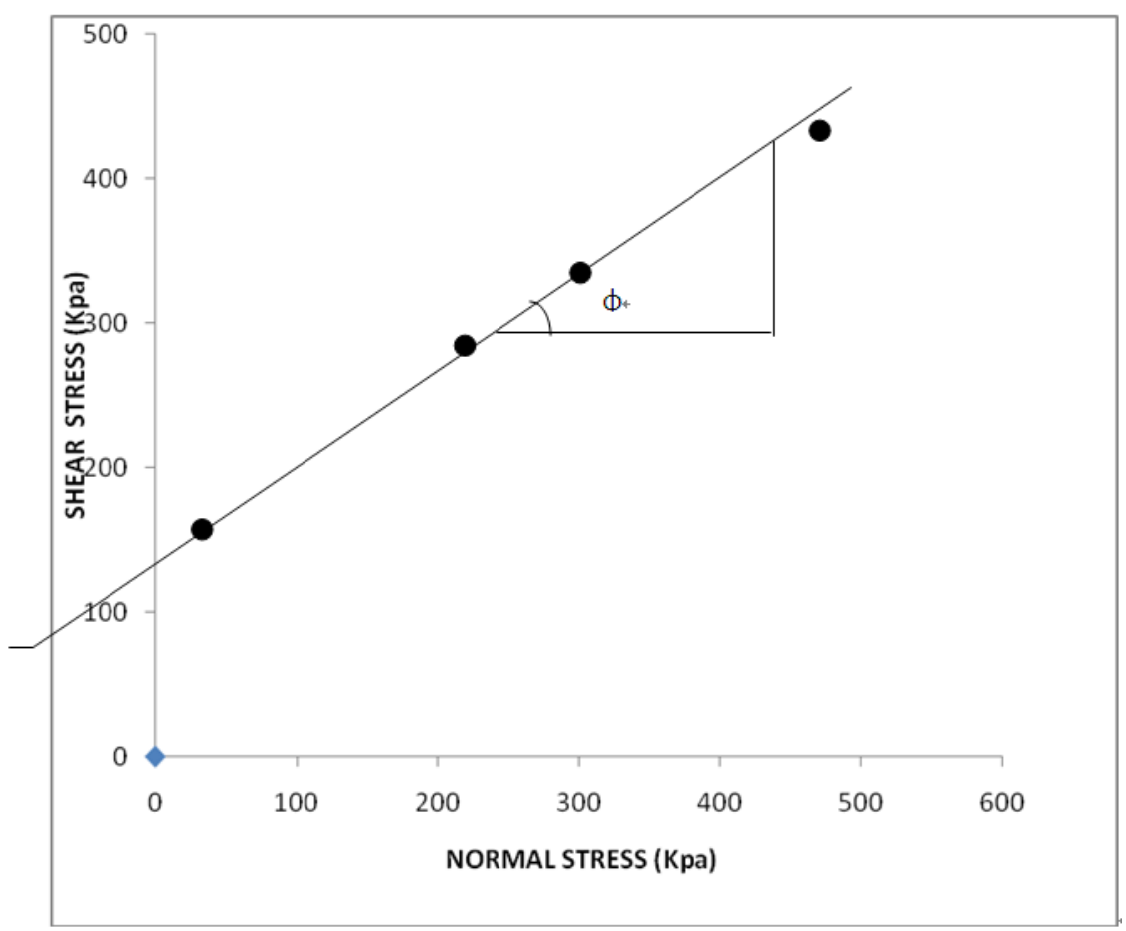

Figure 5b. Plot of shear stress (kpa) vs normal stress (kpa) for standard proctor compacted soil sample ADET 1 


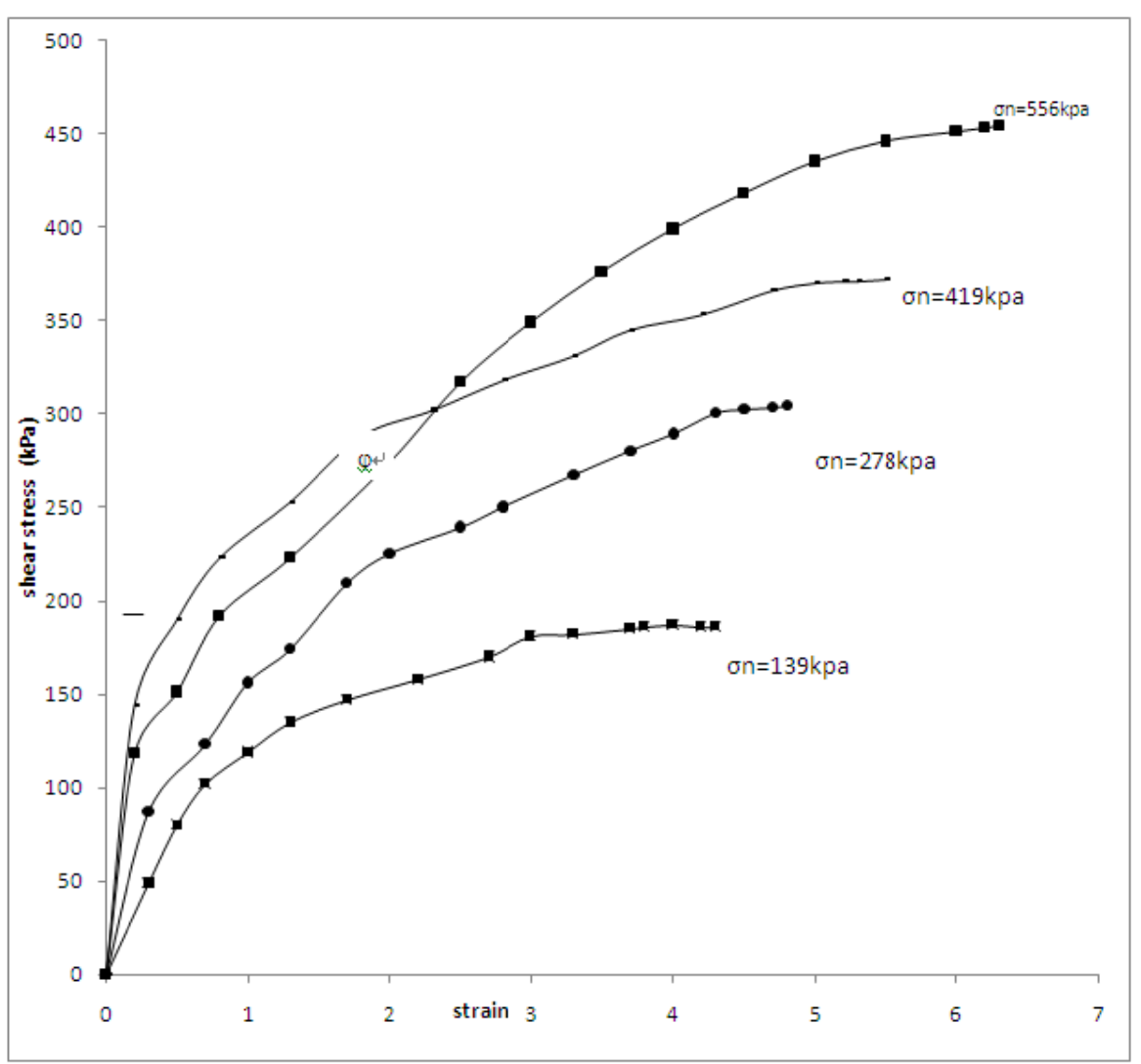

Figure 6a. Plots of shear stress (kpa) vs strain (\%) for modified proctor compacted soil sample ADET 1

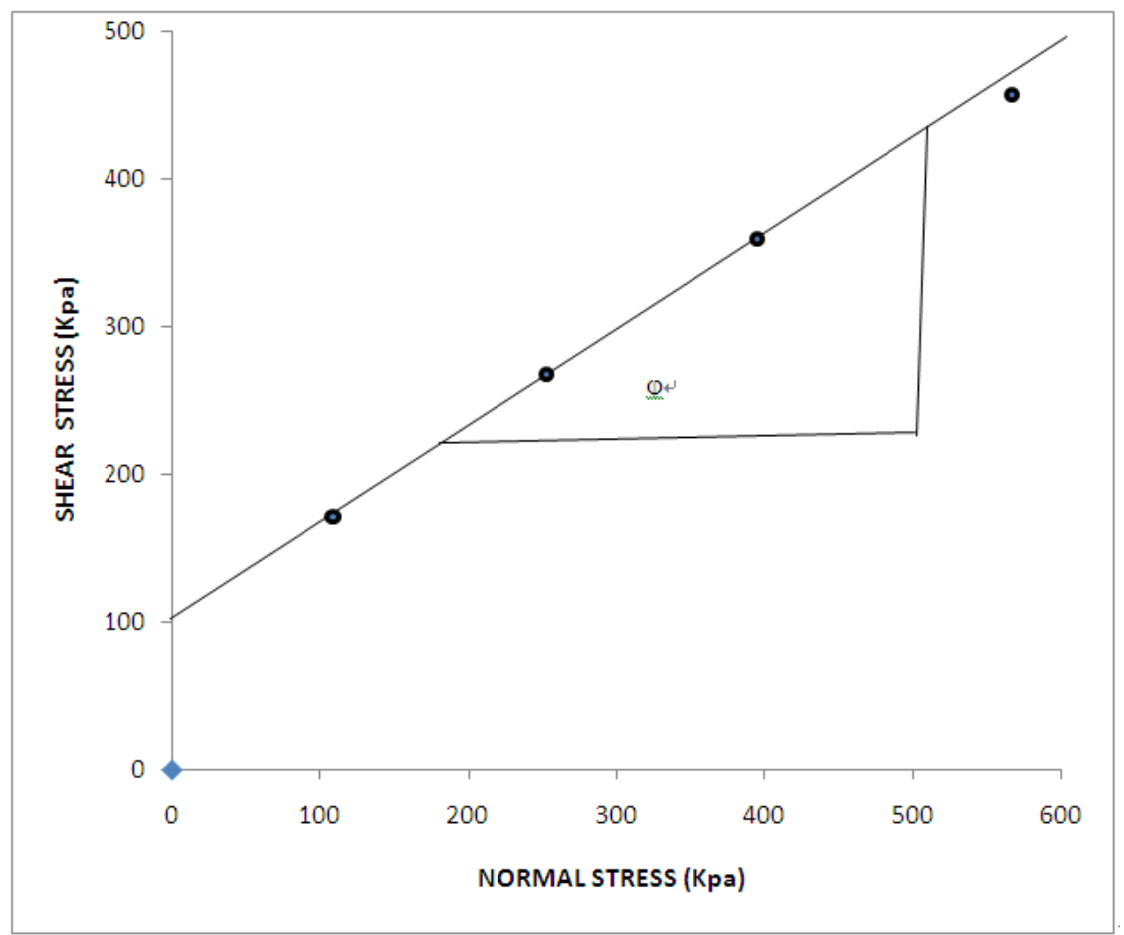

Figure 6b. Plot of shear stress (kpa) vs normal stress (kpa) for modified proctor compacted soil sample ADET1 


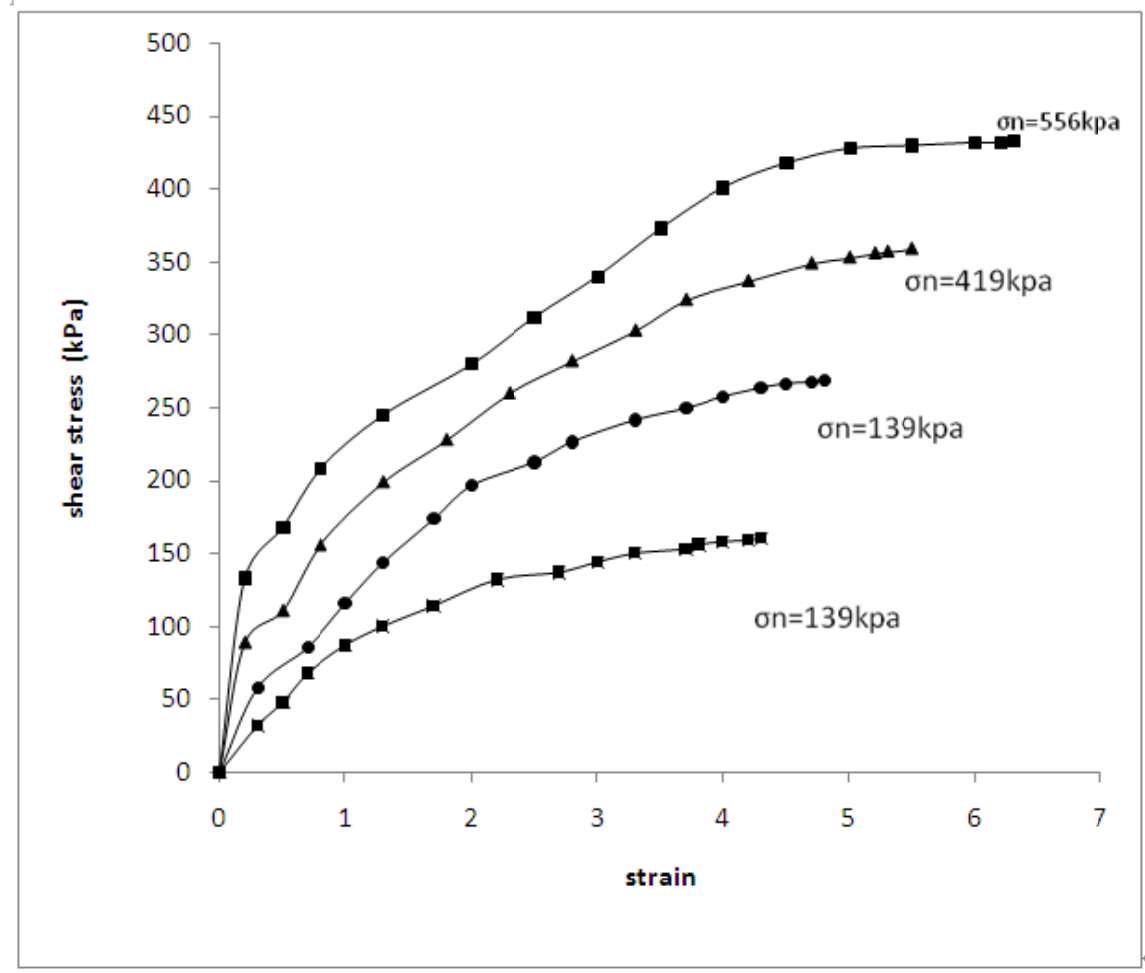

Figure 7a. Plots of shear stress (kpa) vs strain (\%) for standard proctor compacted soil sample ADET 2

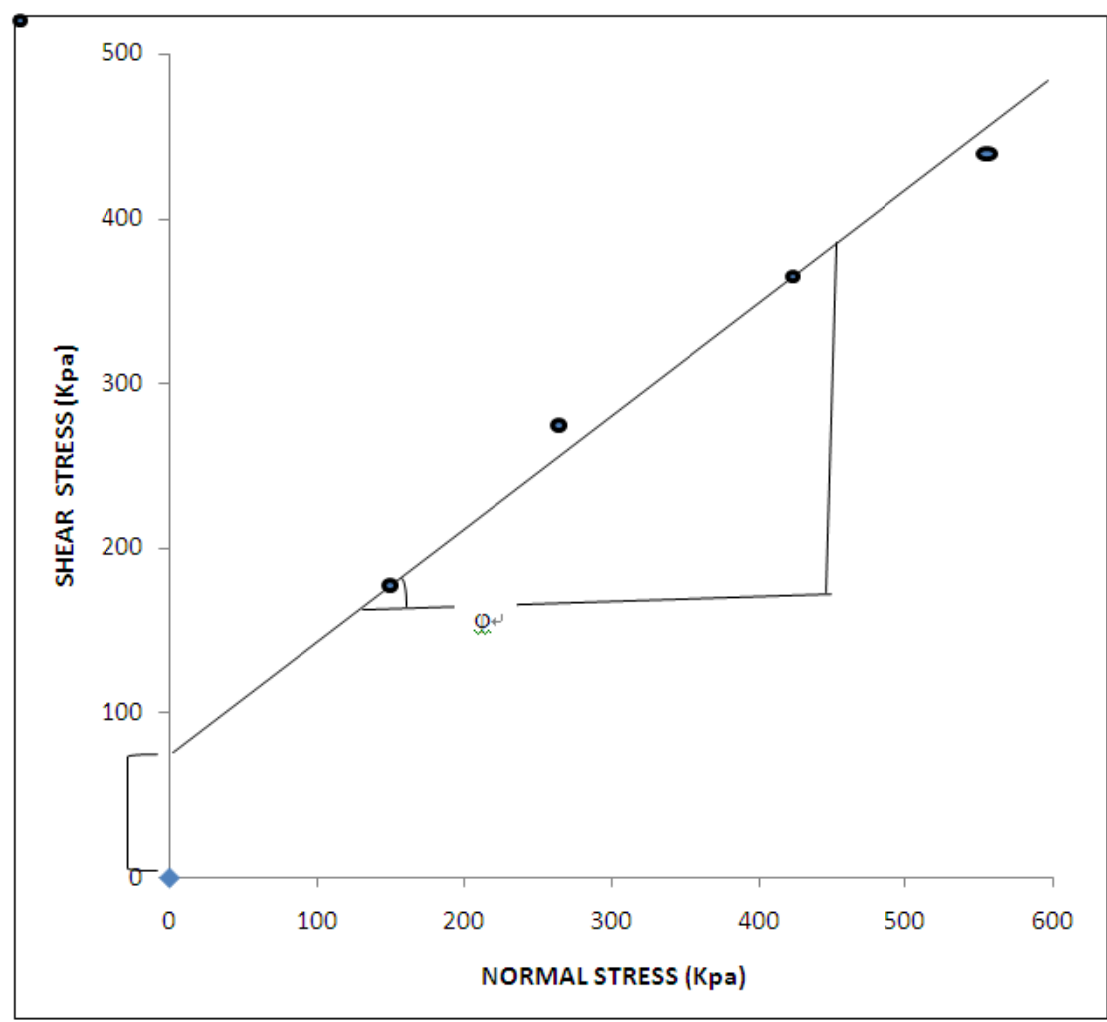

Figure 7b. Plots of shear stress (kpa) vs strain (\%) for standard proctor compacted soil sample ADET 2 


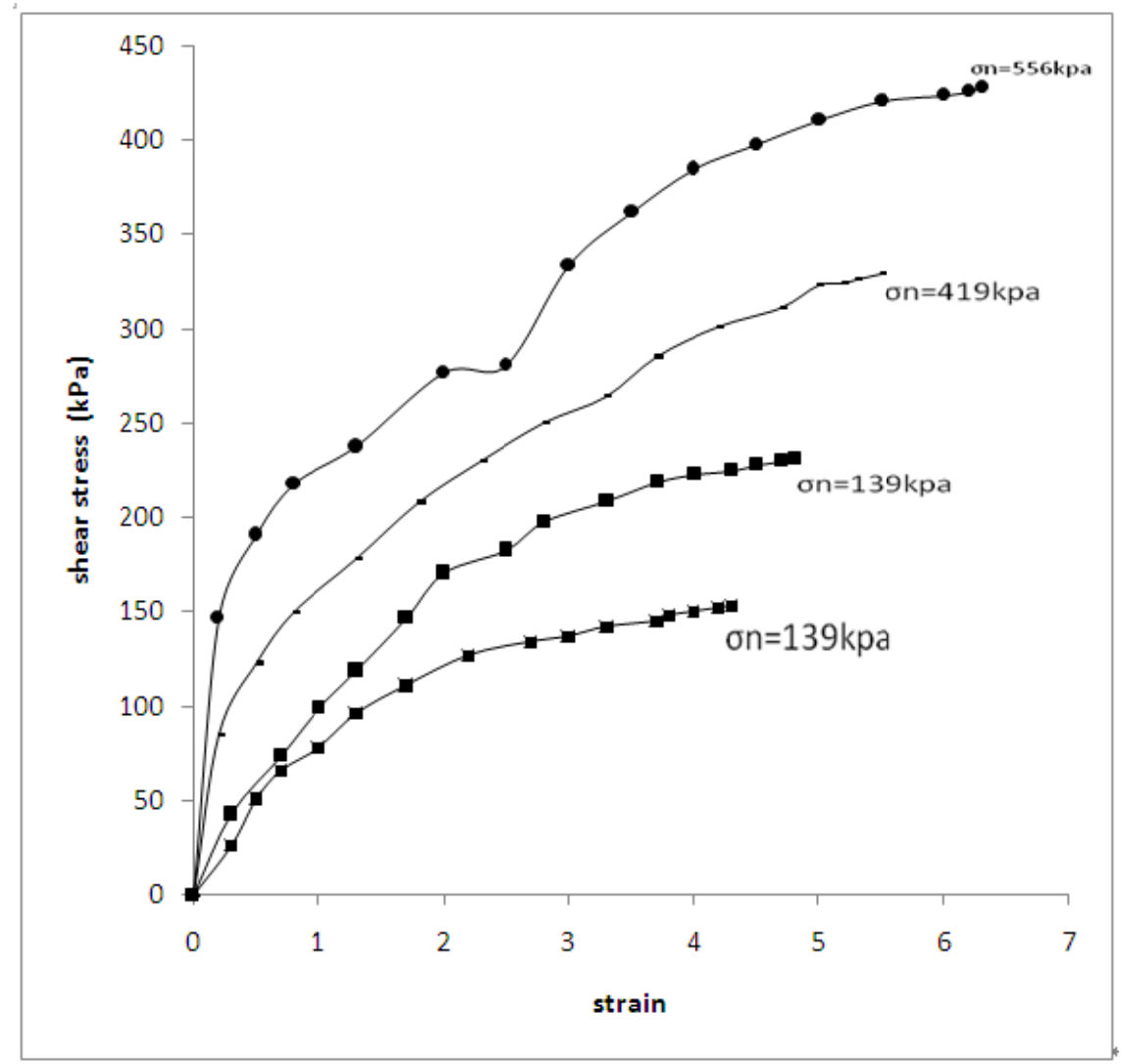

Figure 8a. Plots of shear stress (kpa) vs strain (\%) for modified proctor compacted soil sample ADET 2

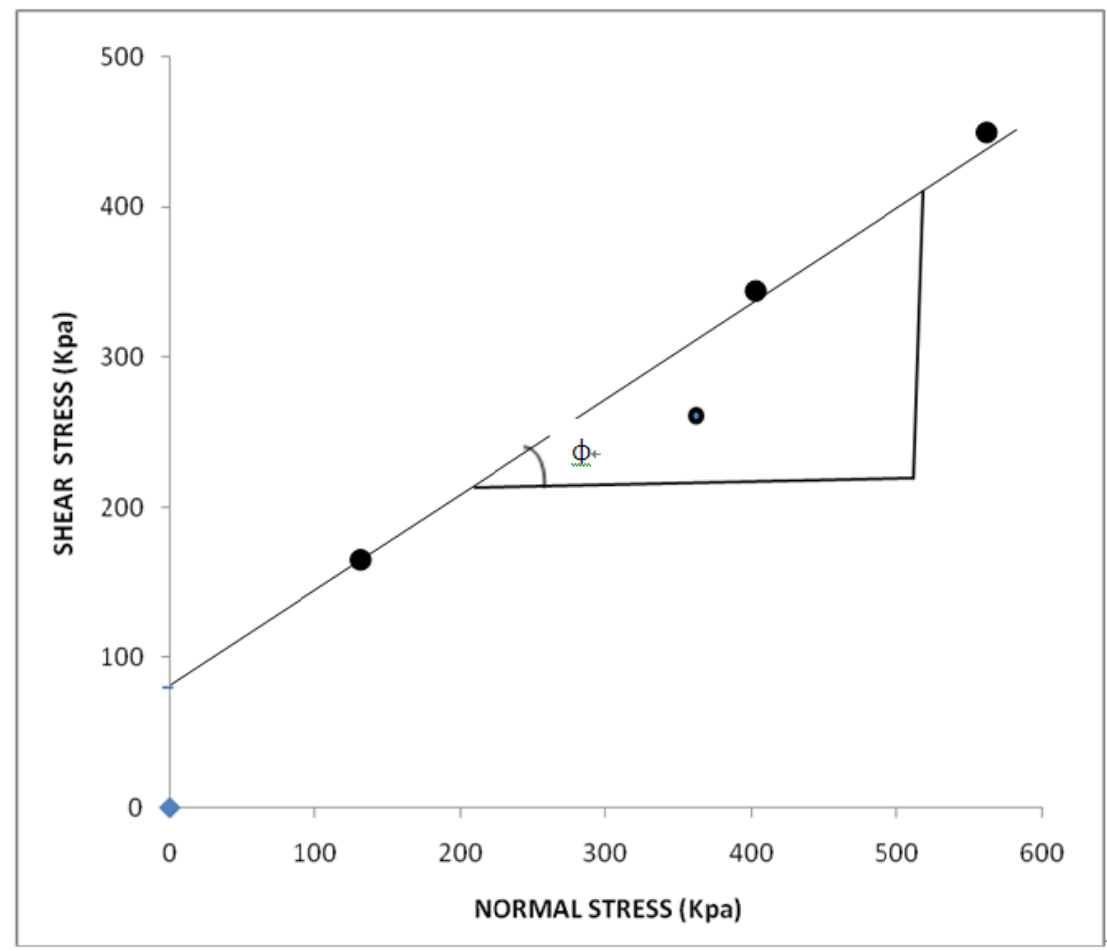

Figure 8 b. Plot of shear stress (kPa) vs. normal stress ( $\mathrm{kPa}$ ) for modified proctor compacted soil sample ADET 2 


\section{Conclusions}

Based on the grain size analysis, the soil sample ADET 1 is silt-clayey very gravelly sand (reddish brown colour) with $30 \%$ gravel, $47 \%$ sand, $23 \%$ silt and clay respectively. ADET 2 exhibits reddish brown colour and is characterized by $12 \%$ gravel, $52 \%$ sand, $36 \%$ silt and clay respectively.

Atterberge consistency limit test indicate that the soil samples are above the activity (A) line in the zone of intermediate plasticity clays (CL and there is negligible or no swelling of soils. Therefore they can be chosen as construction materials in buildings and foundations. The CBR values range from $1-5 \%$. This may make it useful as sub-grade materials in road construction and could also be useful for slope stability.

The direct shear test results give an average value of $33^{\circ}$ for the angle of internal friction and average of $75 \mathrm{Kpa}$ for cohesion. These values are attributed to the high bearing capacity of the soils making them to be useful in slope stability. The foundation design of the area would be shallow foundation and could also support moderately steep slopes to a great height.

Based on the values obtained from the various tests carried out on the soil samples, it could be concluded that they are good road construction materials and can also be used for slope stability and dam constructions.

\section{Acknowledgements}

We appreciate the management of Dall Quarry for the permission granted us to sample the soil in the quarry for this study. Laboratory facility provided by the Civil Engineering workshop of the Department of Civil Engineering, University of Ilorin, Nigeria is gratefully acknowledged. This paper has benefited from valuable contributions from the two anonymous reviewers and we appreciate their efforts.

\section{References}

Alao, D. A. (1983). Geology and Engineering Properties of Lateritic Soil from Ilorin, Nigeria. Engineering Geology, 19, 111-118. http://dx.doi.org/10.1016/0013-7952(83)90029-7

Alao, D. A., \& Opaleye, S. T. (2011). Geotechnical analysis of slope failure of a kaolin quarry at Kura, Jos North-Central. Inter Jour. of Scientific Research, 1(1), 87-102.

Balogun, L. A. (1984). Influence of geological origin on the geotechnical properties of lime-stabilized laterites. Proc., $8^{\text {th }}$ Regional Conf. for Africa on Soil Mechanics and Foundation Engineering. International Society for Soil Mechanics and Foundation Engineering, 1, 355-362.

Bowles, J. E. (1990). Physical and Geotechnical Properties of Soil ( $2^{\text {nd }}$ ed.). Mc Graw-Hill, Inc. p.478.

Das, B. M. (2006). Principles of geotechnical engineering. Stamford, CT: Thomson Learning College.

Gidigasu, M. D. (1972). Mode of formation and geotechnical characteristics of laterite materials of Ghana in relation to soil forming factors. Engineering Geology, 6, 79-150. http://dx.doi.org/10.1016/0013-7952(72)90034-8

Jackson, M. O. (1980). The foundation failure in coastal plain sand of Nigeria. Proceedings of the $7^{\text {th }}$ Regional conference for Africa on soil mechanics and foundation Engineering. Institute of Civil Engineering Accra, 1, 425-430.

Madu, R. M. (1975). Some Nigerian residual lateritic soil, their characteristics and relative road building properties on Group Basis. Proceedings of $6^{\text {th }}$ Regional Conference for Africa Soil Mechanics and Foundation Engineering. Durban, South Africa. International Society for Soil Mechanics and Foundation Engineering, 1, 121- 129.

Ogunsanwo, O. (1988). Basic geotechnical properties, chemistry and mineralogy of some Lateritic Soils from S.W. Nigeria. Bulletin of Engineering Geology, 37, 141-160.

Ogunsanwo, O. (1989). Some geotechnical properties of two Lateritic Soils compacted at different energies. Engineering Geology, 26, 261-269. http://dx.doi.org/10.1016/0013-7952(89)90013-6

Omotoso, O. A., Mamodu, M. O., \& Ojo, O. J. (2011). Evaluation of Geotechnical Properties of Laterite Soils in Asa-Dam area, Ilorin, Southwestern Nigeria.

Vallergra, S. A., Shugter, J. A., Love, A. C. \& Vantil, C. J. (1969). Engineering study of Laterite Soil in connection with construction of Roads, Highways and Airfields. US AID, Report AID/CSD 1980. 165p.

Wagner, A. A. (1957). The Use of Unified Soil Classification System by the Bureau of Reclamation. Proceedings, $4^{\text {th }}$ International conference on soil mechanics and foundation engineering (London), 1, p.125. 